\title{
JUURNAL.RU
}

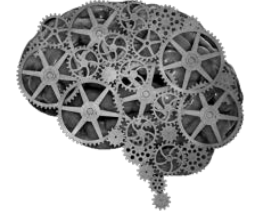

COMPANY GROUP "INTELLEKT"

\author{
Akimbekova A.F. ${ }^{1}$, Abdraimova G.F. ${ }^{2}$, Akimbekov E.T. ${ }^{1}$ \\ ${ }^{1}$ S.Seifullin Kazakh AgroTechnical University \\ ${ }^{2}$ Polytechnic College \\ Astana, Kazakhstan
}

doi: 10.18411/lj2016-8-1-01

idsp 000001: lj2016-17-1-01

\section{Modern educational approaches}

At present the educational process requires fixed enhancement as there is a change of priorities and social values: scientific and technical progress is more and more realized as means to achieve such production rate which in the greatest measure answers satisfaction of constantly increasing needs of the person, development of spiritual wealth of the personality.

Improving the quality of education is a priority direction in the activity of any educational institution, since this criterion would allow the education system to transform itself into a new state, providing a decent level of training and education, adequate needs of developing individual and the labor market.

The teachers of our university actively use the latest innovative teaching methods in the course of lectures, laboratory sessions and seminars for students.

The main forms and training methods which promote training improvement of quality are carrying out occupations by a non-conventional method of training. Important components of modern educational process are innovative techniques of teaching [1].

Currently there is a need to develop new approaches and improving existing common didactic and methodical bases of creation and application of the electronic textbook (ET) in educational systems to improve their effectiveness. In secondary vocational education much attention is paid to computer support professional activities. 
One of the major problems is the question of ensuring educational process by benefits and textbooks of new generation. The main difference of electronic educational resources from traditional textbooks on paper consists that it contains much more information, and also may contain material of illustrative and visual nature, such as video movies from the production, fragments of lecture material, multimedia inserts. One way to improve the quality and interest of the discipline is the creation of electronic manuals. If students are not able to receive several books from the library, students of our educational institution have an opportunity to study on electronic aids. By means of electronic manuals the students have an opportunity during or outside of class to review the information and perform their own workshops. At the same time, our students can practice independently in the library with electronic teaching materials created by our lecturers. These online tutorials, manuals, educational methodical complexes are one of the most effective ways of training. This makes it possible to increase the creativity of the lecturer. For the lecturer the electronic aids is daily developing methodical system, he can develop it constantly.

By means of electronic aids it is possible to show various pictures, schemes, video episodes. It is more effective and leaves more impression than when the teacher explains at the blackboard. Mastering difficult disciplines as physics and biology requires always more profound explanation of disciplines, computers are used for this purpose that is difficult schemes, pictures we show by slides; it in turn increases the interest to a subject and discipline.

Electronic textbooks on physics and biology which are available in our educational institution are created on subjects, sections which consider theories, the basic concepts, tables, tasks, tests.

What great value would be a textbook on the way to knowledge for students now it is known that the value of the computer is increasing as the computer is the tool for knowledge of the environment in the world for future generation [2].

Technologies of electronic devices to be used by electronic aids will allow, in addition to the text, to provide students the opportunity to open audio files, videos, copies of various documents, cross material from other textbooks and encyclopedias [3]. 
The electronic textbook essentially enriches traditional forms of education as allows including in it a huge amount of training and evident materials and promotes development of qualitatively new techniques of teaching.

Perhaps, the only drawback of the electronic textbook is inconvenience reading texts from the monitor screen though any its part at any time can be printed, as well as the modern monitors and computer programs make reading from the screen more and more comfortable.

The electronic textbook is an image of information by different forms, a portable source of knowledge, didactic - methodological and program -interactive tool that is read and stored on a disk. For the purpose of intensive methods of studying and improvement of quality of training demand for electronic textbooks increases.

Electronic textbook in computer-based training system can be a single species, but the set capabilities can be provided in different designs and can be attributed to the ranks of automatic learning systems. In conclusion we can say that the electronic textbook helps learners to self-development, increases the interest in the subject, makes the compilation of personal work, creating special conditions for the development of the individual.

They not only increase information activity, but also help to create logical thinking. Electronic textbooks save our time. Now electronic textbooks on several objects are made up and they are widely used. The most important electronic textbooks occupy a specific place in the inspiration for creativity. 


\section{Литература:}

1. Программа Правительства Республики Казахстан на 2010-2020 гг. //Казахстанская правда. 2010. - 1 апреля.

2. Бабаликова А., Акимбеков Е., Абдраимова Г. Роль информационных технолгии в повышении интереса студентов к дисциплине // «Наука и образование - важнейший фактор развития общества в современных условиях». Международная научно-практическая конференция, Караганды - 2015. Часть II. - C. 234-241.

3. Баранова Ю.Ю., Перевалова Е.А., Тюрина Е.А., Чадин А.А. Методика использования электронных учебников в образовательном процессе. // Информатика и образование. - 2001 - № 8. 